\title{
名古屋市とその周辺地域における熱環境の実態 \\ Thermal Enviromment in Nagoya City and its Surburbs
}

水鳥雅文*、角湯正剛*

By Masafumi MIZUTORI and Masatake KADOYU

\begin{abstract}
The change and its influential factors of the thermal environment of Nagoya City and its suburbs are examined. As a results, the trends of the warming and drying caused by the urbanization in the areas concerned were confirmed quantitatively. The actual conditions of the principal influent factors which were the heat exhaust, change of land use and sea breeze from Ise Bay were grasped, and the relations between these factors and the warming and drying in the area were discussed.
\end{abstract}

Keywords: thermal environment, heat island, urbanization, Nagoya City

\section{1.はじめに}

近年、都市化やエネルギー消費の增加などに伴う都市の温喛化や乾燥化、いわゆるヒートアイランド現象 が社会的な関心と懸念を生んでいる。こうした都市の熱環境に対して有効な改善方策を検討することは、都 市の快適性の增大に貢献するばかりでなく、都市におけるエネルギー供給システムの将来構想を考える上で 重要な課題と言えよう。

本研究は、都市域の熱環境改善に有効な 方策を考案することを目標として、名古屋 市とその周辺地域（以下、名古屋市周辺地 域と呼ぶ）を対象地区に選定し、都市熱環 境の変化とその影響要因（図-1）、具体 的にはエネルギー消費、土地利用形態の変 化や海風の影響について検討するものであ る。

対象とする名古屋市周辺地域は、わが国

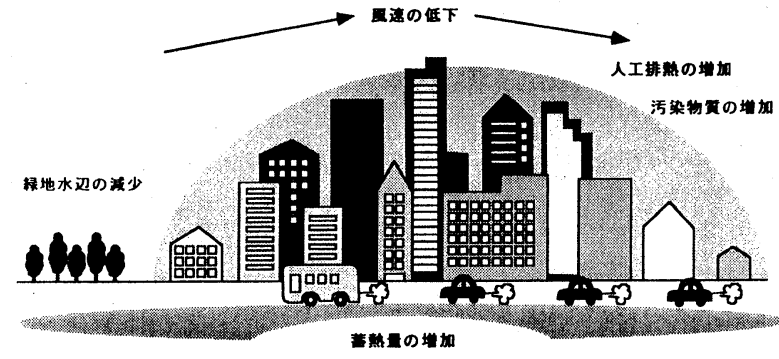

図ー1 ヒートアイランド化の影響要因

* 正会員 工博 (財) 電力中央研究所 我係子研究所

（=270-11 千葉県我孫子市我孫子1646） 
3 大都市圈の一つとして熱環境の悪化が懸念されている地域の一つであるが、その実態については最近北田 ら 2)，32により1975年と1985年の10年間を隔てた熱㻴境変化について検討された程度で、首都圈の場合ほど明 確に把握されているわけではない。本研究では、既往の調查資料に基づき、より詳細な分析を行う。

\section{2. 熱環境の実態}

図-2に名古屋地方気象台 (以下、名古屋之略 す) で観測された最近 100 年間の年平均気温の変動 を示す。名古屋の気温は1920年代や1960年代の半 ばでやや低下傾向がみられるものの、概水漸増傾 向にあると言えよう。しかし、こうした気温変動 には都市化影響ばかりでなく、より大きな空間ス ケール（数 $100 \mathrm{Kkm}$ 以上）の気候変動の影響を含ん でいることに注意しなければならない。

両者の影響を分離することは非常に難しいが、 ここでは一つの試みとして、比較的都市化影響の 小さいと推測される三宅島との気温差をみること により、名古屋での都市化影響による気温変動特 性を検討した。図一 3 は、年平均気温、ならびに 日最高気温および日最低気温の年平均値について、 名古屋の值から三宅島の值を差し引いた差の経年 変化（1950年～1990年）を示す。年平均気温は、 全体的に上昇傾向ながら、1970年代半ばまでのそ の速度は非常に緩やかである。次に日最高気温に ついてみると、多少の変動はみられるものの、顕 著な経年的傾向は見出せない。それに対して日最 低気温は、年平均気温の場合以上に明瞭な上昇傾 向が認められる。また、これら気温の上昇速度は、 年平均気温で約 $0.03^{\circ} \mathrm{C} /$ 年、日最低気温の年平 均值で約 $0.05^{\circ} \mathrm{C} /$ 年である。

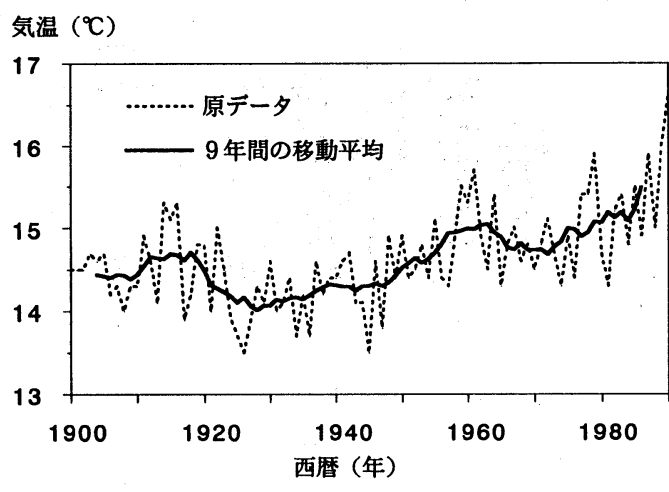

図-2 名古屋の年平均気温の推移
名古屋の気温一三宅島の気温 $\left(^{\circ} \mathrm{C}\right)$

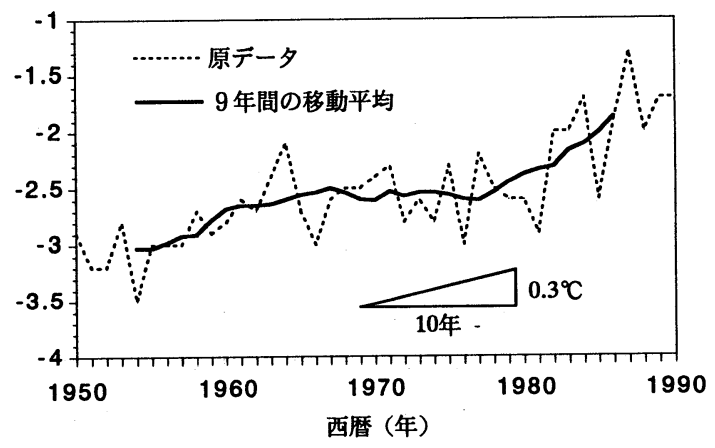

（1）年平均気温

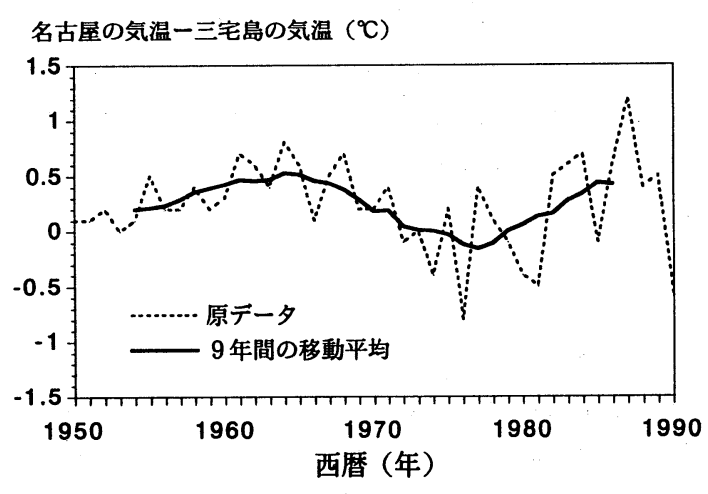

（2）日最高気温の年平均値

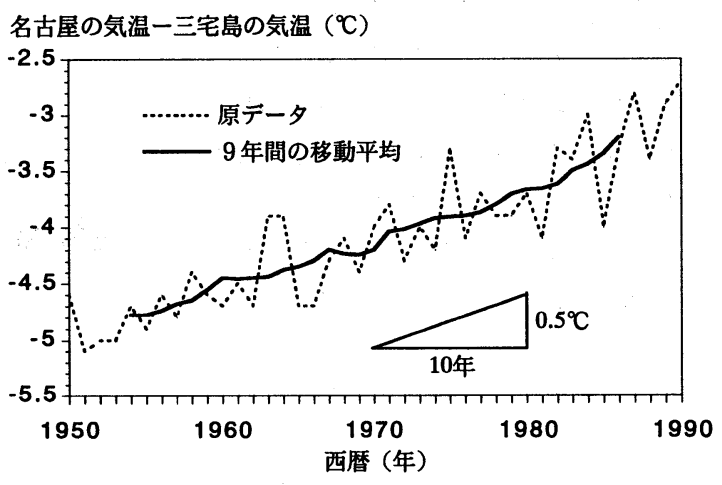

（3）日最低気温の年平均值

図－3 都市化による気温変動

(名古屋と三宅島との気温差の推移) 


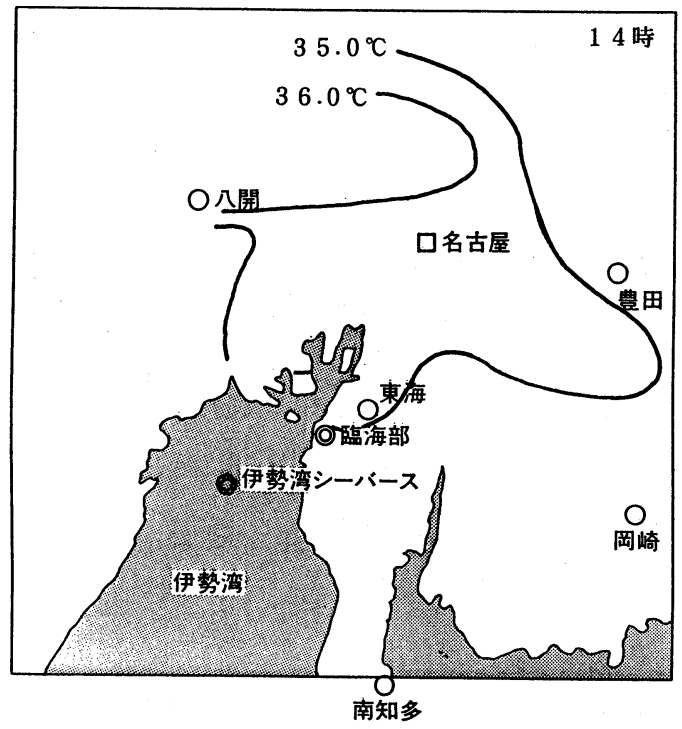

（1）日最高気温（1 4 時）

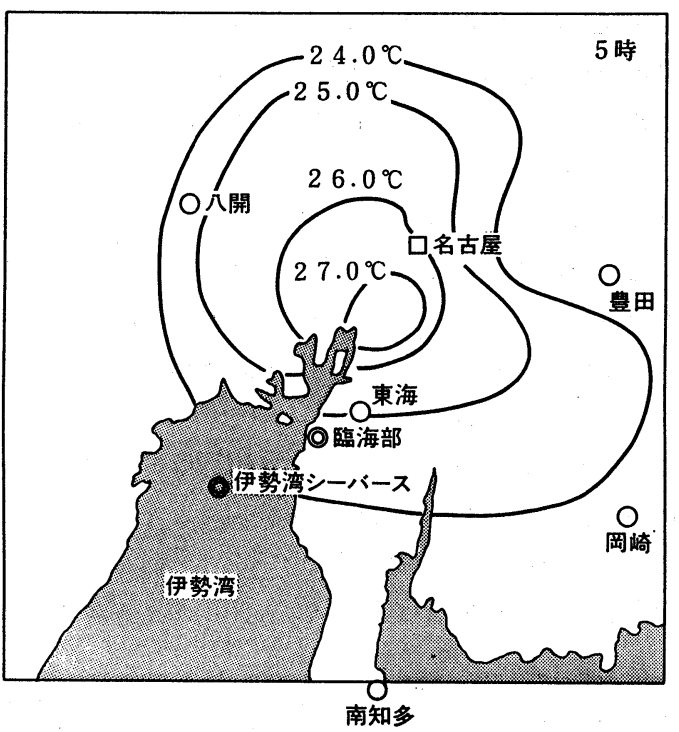

（2）日最低気温（5 時）

図ー4 夏典型日における気温分布

次に1990年夏季のアメダス観測点ならびに大気 測定局での観測データからヒートアイランド現象 の顕在化しやすい典型的な気象条件の日（日照時 間 $10 \mathrm{~h}$ 以上、日平均風速 $3 \mathrm{~m} / \mathrm{s}$ 以下、夜間の天候が快 晴あるいは晴天）を選定し、名古屋市周辺地域の 気温分布特性を検討する。図ー4には、選定した 1990年8月3日から8日の6日間の時刻毎に平均した 気温日変化から求めた日最高気温および日最低気 温の各分布図を示す。日最高気温分布では、分布 の中心がが市中心部よりもやや北西側内陸部にあ るようだが、その気温差はそれほど明瞭ではない。 一方、日最低気温分布をみると、名古屋市中心部 の気温は周忍地域に比へ最大 $3^{\circ} \mathrm{C}$ 程度高く、明瞭 なヒートアイランド化が認められる。既往の研究4) によればヒートアイランド化が最も顕著な時間帯 は夜間から早朝にかけてであり、これらの結果は それをよく裹付けている。

次に、こうした名古屋と周辺地域との気温差の 経年的な推移について検討した。図ー 5 は、図一 4 中に示した周辺地域に点在するアメダス観測点 と名古屋との年平均日最低気温差の経年変化(19 80 1990年）を示す。名古屋市之周辺地域との気 温差は近年挔大傾向にあることがわかる。

こうした気温上昇とともに都市の乾燥化も着目
名古屋の気温一周辺地域の気温 $\left({ }^{\circ} \mathrm{C}\right)$

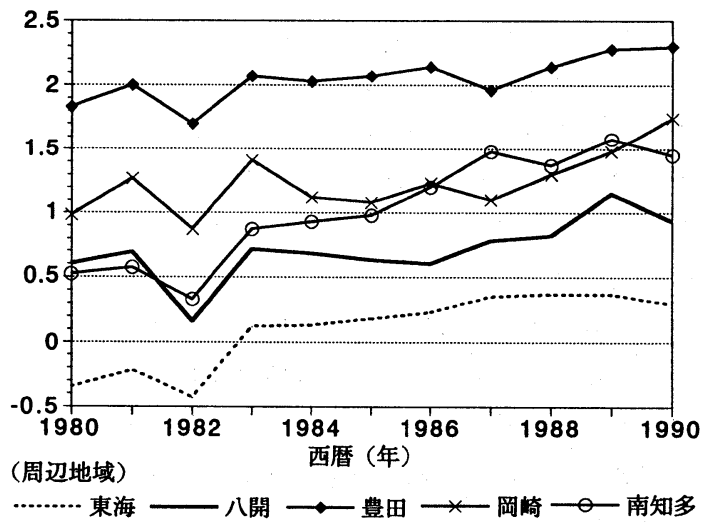

図-5 名古屋と周辺地域との年平均気温差の推移

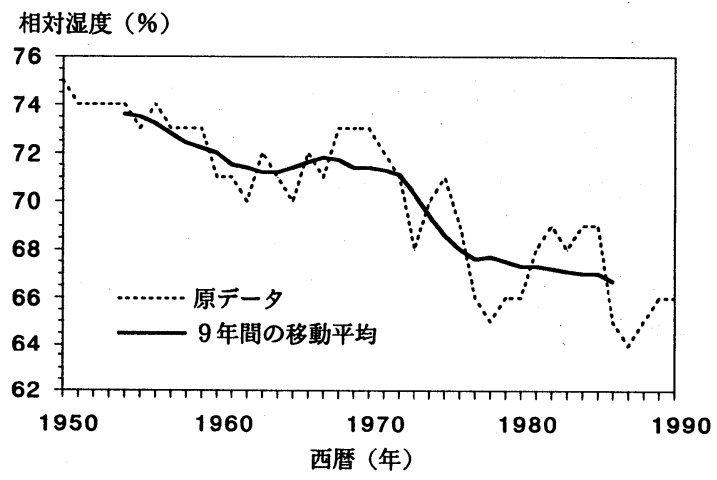

図 -6 名古屋の年平均湿度の推移 
すべき問題である。図-6 は、名古屋市の年平均相対湿度の 経年変化を示す。名古屋市の年平均湿度は約 $0.2 \%$ 年の割合 で乾燥化してきており、特に1970年代に低下傾向が著しい。

\section{3. エネルギー消費の現状と推移}

都市域での活発な生産消費活動はエネルギーの大量消費を もたらし、その結果としての人工排熱の増加がヒートアイラ ンド化の要因の一つとなっていると指摘されている。

図ー 7 は、電力、都市ガス、L P G、重油、ガソリン、軽 油、灯油、石炭の各消費量とそれぞれの用途地区を考虑して 作成した現状(1990年)での名古屋市周辺地域の人工排熱量マ ップ(1 km*1 kmxッシュ)である。これによると、名古屋市の中心 部である中区付近では主に電力、都市ガスおよび自動車（ガ ソリンと軽油）の使用により約 $44.0 * 10^{13} \mathrm{cal} / \mathrm{km}^{2} / \mathrm{y}$ の排熱が あるものと推算される。これは、1990年の名古屋の年平均日 射量 $\left(116 * 10^{13} \mathrm{cal} / \mathrm{km}^{2} / \mathrm{y}\right)$ の約 $40 \%$ に相当する。ちなみに、 東京の市街地での值としては、東京都 ${ }^{5)}$ の $50 * 10^{13} \mathrm{cal} / \mathrm{km}^{2} / \mathrm{y}$

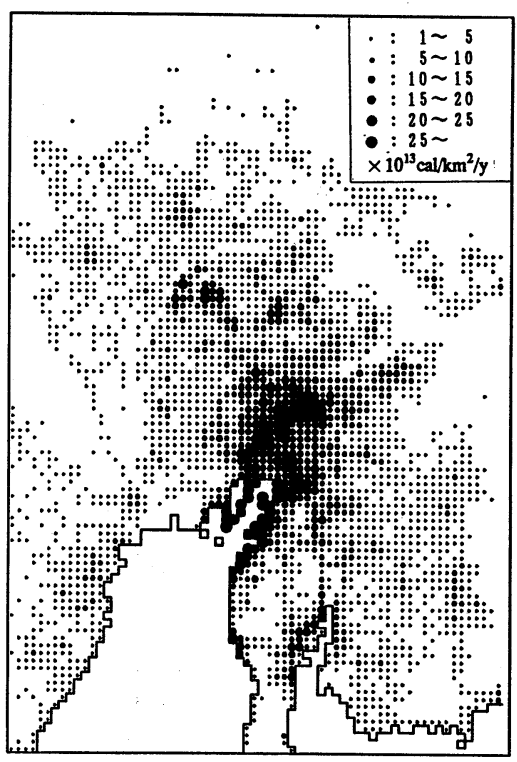

図ー7 人工排熱量マップ pKimura ${ }^{6)}$ の $75 * 10^{13} \mathrm{cal} / \mathrm{km}^{2} / \mathrm{y}$ などの報告があり、 中区付近の排熱量はこれに比べると若干少ないも のの、かなり近い水準にあることがわかる。また、 名古屋港臨海部についても、重油、L P G、石炭 などの消費により市街地に匹敵する排熱量が、推 測されるが、その気温への影響と海風との関連に ついては後に述べる。

図ー8には、名古屋市周辺地域(ここでは尾張 地区に限定）における総人工排熱量のエネルギー 消費からみた構成比（現状）示す。電力消費に伴 う排熱が約 $26.9 \%$ で最も多くの割合を占めている ことがわかる。

図－9に名古屋市における電力および都市ガス の消費の経年変化を示す。両者とむ1970年頃まで は順調に伸び、1970年代はオイルショックの影響 でほほ横ばい状態で推移したが、80年以降ふたた び急激な伸びを示してきている。他のエネルギー 消費む重油など一部を除き漸增傾向にあることか ら、将来的にこうした傾向が継続すると人工排熱 の增加がヒートアイランド化をさらに助長する可 能性がある。

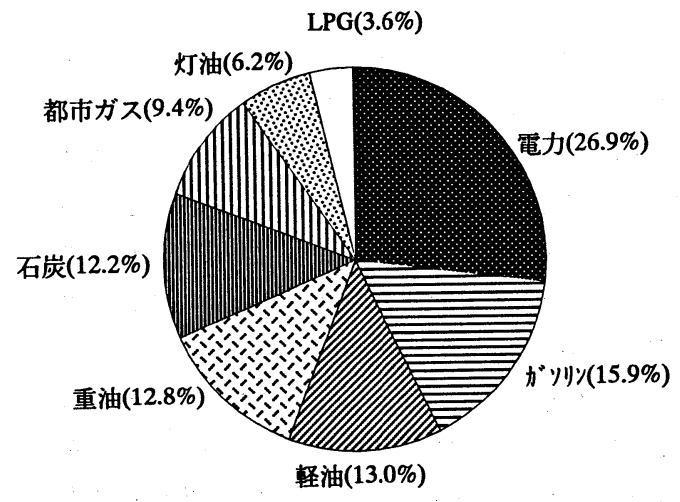

図一8 エネルギー消費からみた総人工排熱量の構成

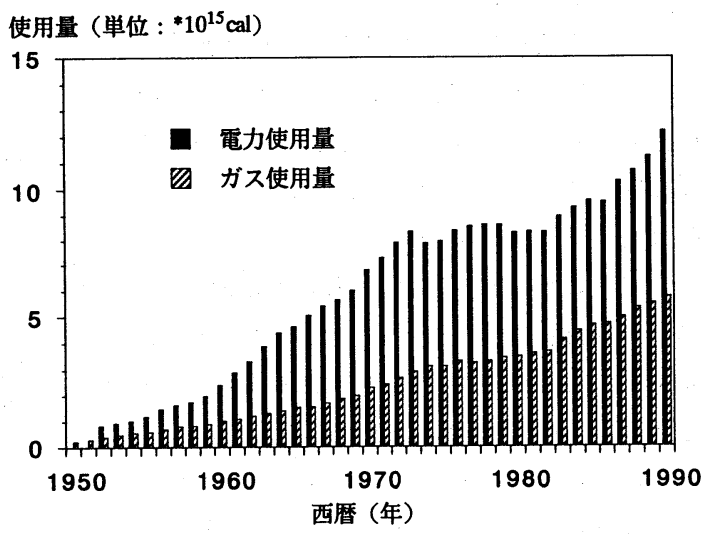

図 - 9 名古屋市における電力・都市ガス使用量の推移 
4.土地利用形態の変化

緑地の單失、道路の舖装化、高層建築物の增加 などといった土地利用形態の変化もヒートアイラ ンド化と深く関連していると考えられている。

図一10は、愛知県ならびに名古屋市における全 民有地面積に対する宅地面積の割合（以下、宅地 率と呼ぶ）の推移を示す。愛知県と名古屋市を比 べと当然のことながら名古屋市の宅地率は著し く高い。また、その増加速度は愛知県、名古屋市 と屯に1970年代に最む大きく、名古屋市の場合は 特に顕著である。この時期は前述の名古屋の相対 湿度の大幅な低下の時期とほぼ一致しており、宅 地化の進展と乾燥化との間の相関が推測される。 ただし、近年の宅地率の增加は徐々に鈍化の傾向 にある。

図ー11には、前述の夏の典型日における対象地 域内の日最低気温と宅地率との相関関係を示す。 両者には明瞭な正の相関があり、宅地化の進行が 乾燥化だけでなく、気温の上昇にも大きな影響を 及ほしていることを示唆している。

\section{5 . 海風の影響}

ヒートアイランドの顕在化しやすい気象条件下 においては、日中伊勢湾から内陸部に向かって海 風が卓越する。図ー12は、前述の夏季典型日にお ける伊勢湾海上（伊勢湾シーバースで観測(図-4参照)）および名古屋での気温の日変化を示す。日中の海 上気温は市内よりも $6^{\circ} \mathrm{C}$ 以上低いことがわかる。図-13は、1990年7月から 1 年間の名古屋港臨海部（図 -4 参 照）と名古屋での日最高気温の月平均値の変化を示す。春季から秋季にかけて臨海部の方が市内よりも1 2 ${ }^{\circ} \mathrm{C}$ 低い。前述のように名古屋港臨海部の人工排熱量は市街地に匹敵するほどであるにも係わらずこのような

気温 $\left(^{\circ} \mathrm{C}\right)$

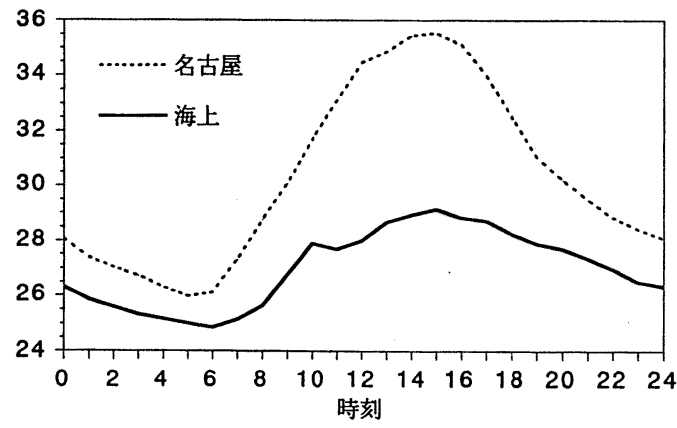

図-12 夏典型日における海上および名古屋の 気温日変化

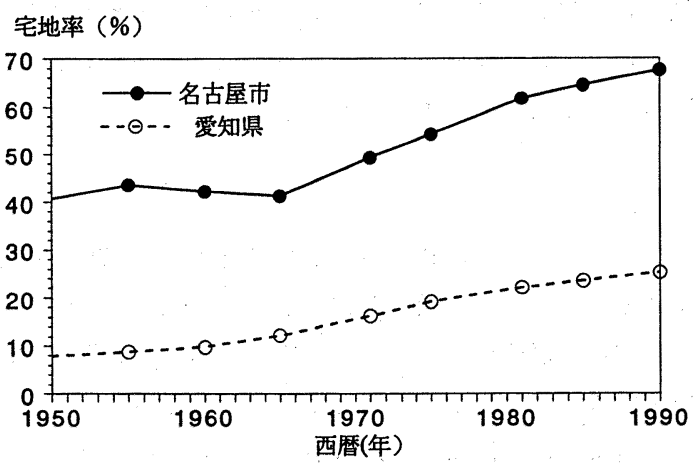

図-10 宅地率の推移

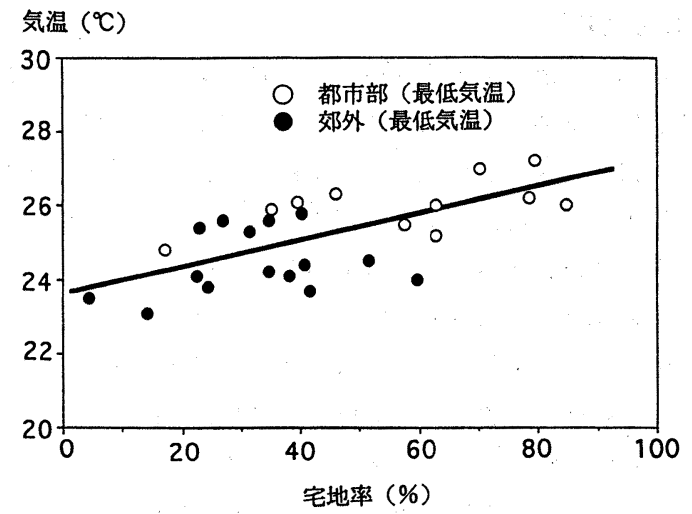

図-11夏典型日における日最低気温と宅地率の相関 
気温差が現れたことは、冷たい海風の効果と推測される。また、こうした海風を都市の高温部へ効果的に導 入すること、つまり「風道」を考えた都市設計をとったならば、日中におけるヒートアイランド化の軽減を 図ることができるかもしれない。

6.おわりに

以上、名古屋市周辺地域における熱環境の現状と推移について分析した。その結果、(1)都市化による温暖 化や乾燥化が着実に進行していること、(2)エネルギー消費に伴う排熱量の增大が近年著しいこと、(3)宅地 化の進行と温暖化や乾燥化との間には明瞭な相関が認められること、(4)伊勢湾からの海風による冷却効果が 期待できること、などの実態が明らかとなった。

今後は、名古屋市周边地域を対象とした都市熱環境シミュレーションモデルを開発し、ヒートアイランド 化の影響要因の定量的な分析を行い、効果的な熱環境改善方策を検討していく予定である。

\section{【参考文献】}

1）水鳥、角湯、電力中央研究所 研究報告 U93016、1-45、1993

2) 北田、国井、久保田、衛生工学研究論文集、27、117-127、1991

3) 北田、久保田、環境システム研究、20、47-53、1992

4）原田：大気污染之気温の変化、東京堂出版、1982

5）東京都情報連絡室 : 東京都地球環境保全行動計画一21世紀にむけて地球を守るために一、1992

6) Kimura, F and Takahashi, S, Atomospheric Environment, 25, 155-164, 1991

7）気象庁：気象年報（全国気象表）、1900 1990

8) 名古屋地方気象台: 愛知県気象月報、1980 1991

9) 愛知県: 愛知県統計年鑑、1950 1991

10)名古屋市：名古屋市統計年鑑、1950 1991 